\title{
Efficacy of Fungicides Applied for Protectant and Curative Activity Against Myrtle Rust
}

\author{
Amin K. Pathan, ${ }^{1, \dagger}$ William Cuddy, ${ }^{2}$ Mark O. Kimberly, ${ }^{3}$ Kwasi Adusei-Fosu, ${ }^{3}$ Carol A. Rolando, ${ }^{3}$ and Robert F. Park ${ }^{4}$ \\ ${ }^{1}$ Ministry for Primary Industries, Rotorua, New Zealand \\ ${ }^{2}$ NSW Department of Primary Industries, Elizabeth Macarthur Agricultural Institute, Menangle NSW 2568, Australia \\ ${ }^{3}$ Scion, Rotorua 3046, New Zealand \\ ${ }^{4}$ Plant Breeding Institute, School of Life and Environmental Sciences, The University of Sydney, Narellan, NSW 2567, Australia
}

\begin{abstract}
Myrtle rust, caused by the pathogen Austropuccinia psidii, affects species of the Myrtaceae, many of which are endemic to Australia and New Zealand. Originating from South America, A. psidii is now present in both countries, necessitating effective chemical control for disease management. Using an artificial inoculation protocol, the efficacy of eight fungicides (tebuconazole/trifloxystrobin, cyproconazole/azoxystrobin, fosetyl aluminum, triforine, triadimenol, oxycarboxin, copper, and tebuconazole) applied as curative or protectant treatments was tested on two native New Zealand species (Lophomyrtus $\times$ ralphii and Metrosideros excelsa). The impacts of rate $(\times 2)$, frequency (single or double), and timing (preor postinfection) of fungicide application were investigated. Overall,

(Amistar Xtra). These fungicides significantly reduced infection of host plants relative to the water control. Timing of application significantly affected bioefficacy, with applications made 7 days before inoculation or 7 days after inoculation being generally the most effective. The rate of fungicide application was not significant for both host species, with few interaction terms showing overall significance. Key findings from this study will set the foundation for further fungicide bioefficacy research conducted to evaluate formulations and adjuvant mixtures, determine suitable application methods for enhanced retention and coverage, and derive optimum application time for effective protection of native and exotic Myrtaceae species in New Zealand.
\end{abstract} the most effective fungicides tested across both species were those that included a demethylation inhibitor and strobilurin mix, notably tebuconazole/trifloxystrobin (Scorpio) and cyproconazole/azoxystrobin
Keywords: strobilurin, demethylation inhibitor, Austropuccinia psidii, disease management, inoculation, fungicide bioefficacy, myrtle rust
Myrtle rust, also known as guava rust, eucalypts rust, or 'ōhi'a rust, is a disease caused by a pathogen Austropuccinia psidii (G. Winter) Beenken (syn. Puccinia psidii, Uredo rangelii) (Beenken 2017; Simpson et al. 2006; Winter 1884). This biotrophic plant pathogen was first reported in 1884 on guava (Psidium guajava; Winter 1884 ) in Brazil and has since spread across the globe (Carnegie and Pegg 2018). A. psidii infects members of the plant family Myrtaceae, which includes Eucalyptus species and, in New Zealand, several iconic indigenous species such as Metrosideros spp., Lophomyrtus spp., and Kunzea spp., all of which are important to the country's indigenous ecosystems, cultural values, and economy (e.g., honey, oil, and tourism). When infections are severe, leaves and stems become deformed with significant defoliation, often to the extent that host mortality occurs (Coutinho et al. 1998; Glen et al. 2007; Uchida and Loope 2009). Because of the potentially devastating impacts of myrtle rust to the New Zealand native flora, prior to its detection in New Zealand in May 2017 (Beresford et al. 2018), there was considerable concern as to the consequences should an incursion occur (Clark et al. 2011).

${ }^{\dagger}$ Corresponding author: A. K. Pathan; amin.pathan@mpi.govt.nz

Funding: Funding was provided by Ministry for Primary Industries, New Zealand.

*The $\boldsymbol{e}$-Xtra logo stands for "electronic extra" and indicates that two supplementary tables are published online.

The author(s) declare no conflict of interest.

Accepted for publication 4 March 2020.

This article is in the public domain and not copyrightable. It may be freely reprinted with customary crediting of the source. The American Phytopathological Society, 2020.
There have been comprehensive reports on the biology, wide host range, and geographical distribution of $A$. psidii (Berthon et al. 2018; Carnegie and Pegg 2018; Carnegie et al. 2016; McTaggart et al. 2018). The biosecurity threat from a potential myrtle rust incursion in Australasia was recognized by Australian scientists almost 40 years ago (Commonwealth Department of Primary Industries 1985), following the reports of the rust killing swathes of young flooded gums (Eucalyptus grandis) in Brazilian plantations and nurseries in 1973 (Ferreira 1983). At the time, Australian plant pathologists were concerned about the impact this pathogen could have on native Myrtaceae in Australia. The pathogen was subsequently detected in Florida in 1977 and severely damaged native Australian broad-leaved paperbarks (Melaleuca quinquenervia) (Marlatt and Kimbrough 1979). The Australian mycologist John Walker predicted that the rust would be an "ecological disaster" if it entered Australia, where about $10 \%$ of flora are Myrtaceae (Walker 1996). Myrtle rust was subsequently detected in New South Wales in April 2010 on three species of native plants (Agonis flexuosa, Syncarpia glomulifera, and Melaleuca viminalis), followed by detections in Queensland in December 2010 (Pegg et al. 2014). With a rapidly expanding distribution, including amenity and native plantings, the disease was considered ineradicable by the Australian authorities in late 2010 (Carnegie and Cooper 2011). The pathogen was first reported in New Zealand in April 2017 on Raoul Island, and subsequently observed on the mainland including regions such as Taranaki, Waikato, and the Bay of Plenty, infecting both native and exotic Myrtaceae in nurseries and forest reserves (Beresford et al. 2018). In New Zealand, 29 indigenous Myrtaceae species were provisionally identified as at risk, with the most susceptible species likely to be ramarama (Lophomyrtus bullata), pōhutukawa (Metrosideros excelsa), rohutu (Neomyrtus pedunculata), southern rata (Metrosideros umbellata), northern rata (Metrosideros robusta), and mānuka (Leptospermum scoparium) (Ganley and Beresford 2018).

Since the incursion of myrtle rust into the New Zealand mainland, several governmental bodies, including the Ministry for Primary Industries and the Department of Conservation, have taken steps to 
eradicate and manage the spread of the pathogen (Beresford et al. 2018). Methods to control the spread of inoculum were mostly physical removal of plants for scenarios ranging from urban to native environments, infected isolated trees, or nurseries. This included the use of a concrete sealer on infected plants to "lock" spores before removal. Trees that were too large to be covered by concrete sealer (and deemed to be prone to off-target drift) were sprayed with cuprous oxide, although the efficacy of this method remains untested. The Ministry for Primary Industries also recommended use of a copper oxide spray on top of concrete sealing a day before removal of infected trees to kill spores not "locked" in by the concrete sealer (Chang et al. 2018). Following concrete sealing, infected trees were removed to stump level, cut into smaller pieces, and triple bagged or placed through a chipper into triple-lined garden waste bags or shipping containers.

For effectively protecting at-risk Myrtaceae species, there is a need to identify suitable fungicides or biological control methods to assist in the management of $A$. psidii and its impacts in New Zealand (Chang et al. 2018). Management of rust diseases through chemical methods is challenging due to a range of influencing factors that are intrinsic and extrinsic to the plant as well as the pathogen. However, the severity of spread and infection could be attenuated via chemical control, as has been demonstrated in Brazil (Alfenas 2004; Martins et al. 2011; Masson et al. 2011, 2013; Moraes et al. 2011) and Australia (Carnegie et al. 2016). The most effective chemical groups for control of myrtle rust have been shown to be the demethylation inhibitor fungicides (triadimenol, cyproconazole, and tebuconazole) and the strobilurins (such as azoxystrobin and trifloxystrobin) mixed with the triazole fungicides, such as a combination of azoxystrobin + cyproconazole + thiamethoxam, one of azoxystrobin + difenoconazole, and one of trifloxystrobin + tebuconazole (Masson et al. 2013). The application of chlorothalonil, mancozeb, and copper oxychloride as preventative treatments has also been shown to be effective on P. guajava (Ferrari et al. 1997). To date, most of the myrtle rust chemical control studies have been carried out in South America (Alfenas et al. 1993; Martins et al. 2011; Ruiz et al. 1991), testing mostly the efficacy of single active ingredients or mixtures (Masson et al. 2011, 2013), and usually evaluated for biological efficacy using single fungicide dose applications and single fungicide applications. Carnegie et al. (2016) used triadimenol applied as a preventative treatment on Myrtaceae in natural ecosystems in Australia, to demonstrate the severe damage A. psidii caused to endemic Myrtaceae, after 4 years' exposure to the pathogen.

Prior to the current study, chemical control research for effective management of A. psidii on native Myrtaceae had not been carried out in New Zealand. Based on the work conducted in Brazil and Australia, as described above, nine fungicides (triadimenol, trifloxystrobin, azoxystrobin, mancozeb, tebuconazole, propiconazole, triforine, copper oxychloride, and oxycarboxin) were publicly recommended for use against $A$. psidii in New Zealand; however, the level of biological efficacy of these chemicals as curative or protectant treatments on New Zealand Myrtaceae was largely unquantified. Using an artificial spore-inoculation system, the aim of the work presented here was to determine the effect of different fungicide products applied as curative or protectant treatments on infection of two native New Zealand species (Lophomyrtus $\times$ ralphii and $M$. excelsa) by A. psidii. With an objective to derive practical recommendations for effective management of myrtle rust, the impact of rate, frequency, and timing of fungicide application on bioefficacy was also investigated.

\section{Materials and Methods}

Plants and inoculation procedure. Two Myrtaceae species, $M$. excelsa 'Nana' and $L . \times$ ralphii 'Black Stallion', were used in this trial. $L . \times$ ralphii is a naturally occurring hybrid between the two native New Zealand Lophomyrtus species (L. bullata and L. obcordata) but has also been extensively bred to create different cultivars. These were the only two susceptible New Zealand native plant species that could be sourced in Australia. The M. excelsa plants were sourced in $135 \times 140-\mathrm{mm}$ pots as small shrubs and were approximately $100 \times$
$100 \mathrm{~mm}$ in size. The $L . \times$ ralphii plants were sourced as tubestock in $40 \times 125-\mathrm{mm}$ pots and were approximately $50 \times 100 \mathrm{~mm}$. Plants were growing in premium potting mix and were kept in a shade house facility at the Elizabeth Macarthur Agricultural Institute, Menangle, NSW, under ambient conditions in October and November 2017. Plants were not watered directly on foliage to ensure no interference with fungicide applications. Plants were maintained in the shade house for 2 weeks prior to the start of the first fungicide applications and were kept in the shade house until inoculation with myrtle rust occurred. After inoculation, plants were split by species and then maintained in a completely randomized design in a greenhouse at the Elizabeth Macarthur Agricultural Institute at $22 \pm 2{ }^{\circ} \mathrm{C}$ under ambient light and humidity conditions.

A standard culture (Plant Breeding Institute collection rust culture no. 622) of A. psidii was used for artificial inoculation of plants. This is the same pandemic strain that spread through the Australasian countries. The inoculum of $A$. psidii for use in the artificial inoculation process was bulked up in a controlled environment on Syzygium jambos plants, which are highly susceptible to myrtle rust. Prior to inoculation of the host species, spore viability was assessed using the Tessmann and Dianese (2002) protocol. After viability was determined, spores were counted with an average of 325 urediniospores/ $\mathrm{cm}^{2}$ suspended in Isopar L Paraffin oil (Univar, Ingleburn, NSW, Australia). These were applied onto seedlings using an Iwata air brush and air compressor calibrated to 25 psi. Inoculated plants were incubated for $36 \mathrm{~h}$ in the dark at $20^{\circ} \mathrm{C}$ at $100 \%$ relative humidity, maintained via the ultrasonic humidifiers in the inoculation room cabinets. After incubation, plants were transferred to the greenhouses at the Elizabeth Macarthur Agricultural Institute, Menangle, Australia, and maintained at $22 \pm 2{ }^{\circ} \mathrm{C}$ under ambient light and humidity conditions.

Trial design and treatments. Five fungicide products were tested on both $L$. $\times$ ralphii and M. excelsa, and a further three products were tested only on $L . \times$ ralphii. Each product was tested at the label rate (rate 1) and twice the label rate (rate 2) to determine the effect of a higher dose on fungicide bioefficacy against $A$. psidii (Table 1). Fungicides were applied at 14 days preinoculation (Pre-14), 7 days preinoculation (Pre-7), 7 and 17 days postinoculation (Post-7/17), 14 and 24 days postinoculation (Post-14/24), and 21 days postinoculation (Post-21) (Table 2). These treatments were designed to determine the optimum time period over which the fungicides would be most effective before inoculation (pretreatments) or postinoculation (posttreatments). Treatments were applied using a Generation III Research Sprayer booth (DeVries Manufacturing, Hollandale, MN) fitted with a TeeJet DG11002 flat-fan nozzle calibrated to apply fungicides (treatments) at a rate of 500 liters $/$ ha at $50 \mathrm{~cm}$ above the plant canopy. For each product tested, there were therefore 10 treatment combinations (two rates $\times$ five application times). Control plants treated with water only were also included in the trial for each host species. The fungicide treatments were applied to individual plants in a completely randomized design with five replicate plants per treatment combination. Plants were selected randomly for treatment and were positioned randomly within a section of the greenhouse. In all, $275 \mathrm{M}$. excelsa and $425 \mathrm{~L}$. $\times$ ralphii seedlings were used in this trial.

Disease assessments. The M. excelsa plants were assessed 15 and 35 days after inoculation. For the first assessment, the percentage leaf area affected (LAA) was scored on the adaxial surface of three randomly selected leaf pairs that were fully emerged at the time of inoculation to give a total of six LAA measurements per plant. These values were averaged to give the representative LAA per plant. At 35 days after inoculation the LAA was again assessed. The $M$. excelsa plants generally grew a new pair of leaves every week and were prone to new infections. Hence, at the second assessment, the LAA was determined by scoring only the percentage leaf area affected by actively sporulating pustules for the pair of leaves that were fully emerged on the dominant stem at the time of inoculation, with separate scores for the abaxial and adaxial sides of the leaf.

The $L . \times$ ralphii plants were scored 18 and 35 days after inoculation. For the first assessment, LAA was scored on both leaves of the 
highest leaf pair that was fully emerged at the time of inoculation and averaged to give the LAA per plant. The internode below the fully emerged leaves was also scored to indicate the internode area affected (IAA). Due to severe leaf necrosis caused by A. psidii infections in $L . \times$ ralphii during the trial, at the second assessment 35 days after inoculation only the actively sporulating pustules on the same internode were scored. For this second assessment, the internode was scored from 1 to $4: 1$ indicated clean (i.e., no infection); 2 indicated a completely killed infection (indicated by necrotic tissue with no active sporulation); 3 indicated an infection that was $>50 \%$ killed but with some actively sporulating pustules still on stems; and 4 indicated actively sporulating pustules on the internode region with no obvious interruption to infection from fungicide treatments.

Statistical analysis. Analyses of variance (ANOVAs) were used to test treatment effects for each plant species. A separate ANOVA was fitted for each combination of species and infection assessment variable. The ANOVA structure included four experimental factors. The first was a factor called "Treated versus Control" with two levels used to test the overall contrast between plants sprayed with fungicide versus control plants sprayed only with water. The other three experimental factors were all nested within the Treated level of Treated versus Control. These consisted of a three-factor factorial design testing the effects of fungicide (active ingredient) (Table 1), application rate (rate 1 versus rate 2), and timing of application (Table 2), and all interactions between these three factors. Tukey's test was used to perform pairwise comparisons between fungicide formulations and between timing treatments. All analyses were carried out using the SAS version 9.4 general linear model (GLM) procedure.

Prior to analysis, all assessment variables were checked for normality using the SAS UNIVARIATE procedure. The angular transformation (equation 1) was used for achieving normality for all LAA and IAA measurements, and all LAA and IAA measurements were therefore transformed prior to analysis based on equation 1 :

$$
y=\sin ^{-1}(\sqrt{x / 100})
$$

The 35-day infection score used for $L . \times$ ralphii did not require transformation.

\section{Results}

The analysis indicated that for the two host species there was a significant difference in infection scores between seedlings sprayed with a fungicide compared with control plants sprayed with water at both assessment dates for Treated versus Control (Tables 3 and 4, Supplementary Tables S1 and S2). Infections were also observed on the adaxial leaf surfaces, abaxial leaf surfaces, and internodes of plants used for the study. The main effect of fungicide was also statistically significant $(P=0.0002$ for M. excelsa; $P<0.0001$ for $L . \times$ ralphii) across all disease assessment variables for both host species, indicating significant differences in infection scores between the different fungicide formulations (Supplementary Tables S1 and S2; Tables 3 and 4). Assessed over all levels and based on the mean scores recorded for disease assessment at 35 days in M. excelsa and $L$. $\times$ ralphii, the two most effective formulations were the tebuconazole/ trifloxystrobin mix (Scorpio) and the azoxystrobin/ cyproconazole mix (Amistar Xtra), with triadimenol (Bayfidan 250 EC) and triforine (Saprol) not significantly different from these top treatments for the 35-day LAA assessment in M. excelsa (Tables 3 and 4). The infection scores recorded for both species treated with either of the mixtures (tebuconazole/trifloxystrobin or azoxystrobin/ cyproconazole) were not significantly different (Tables 3 and 4). In $L . \times$ ralphii, tebuconazole applied as a stand-alone fungicide reduced the severity of infection at the 18-day LAA assessment, but infection scores were significantly higher than the tebuconazole/ trifloxystrobin mix treatment by the 35-day IAA assessment (Table 4). The levels of infection, or pustule development, was observed to be clearly higher on the abaxial than the adaxial leaf surfaces for $M$. excelsa.

Table 1. Fungicides and rates tested in a trial to determine their efficacy for control of Austropuccinia psidii on two native New Zealand Myrtaceae species ${ }^{\mathrm{z}}$

\begin{tabular}{|c|c|c|c|c|c|c|}
\hline \multirow{2}{*}{$\begin{array}{l}\text { Fungicide } \\
\text { product }\end{array}$} & \multicolumn{2}{|c|}{ Active ingredient(s) } & \multirow{2}{*}{$\frac{\text { FRAC Group }}{3}$} & \multirow{2}{*}{$\frac{\text { Manufacturer }}{\text { Bayer }}$} & \multirow{2}{*}{$\begin{array}{c}\begin{array}{c}\text { Rate } \mathbf{1}(\mathbf{m l} \text { or } \mathbf{g} \text { per } \\
\mathbf{5 0 0} \mathbf{~ m l} \text { of solution) }\end{array} \\
0.375 \mathrm{ml}\end{array}$} & \multirow{2}{*}{$\begin{array}{l}\text { Rate } \mathbf{2}(\mathbf{m l} \text { or } \mathbf{g} \text { per } \\
\mathbf{5 0 0} \mathbf{~ m l} \text { of solution) } \\
0.75 \mathrm{ml}\end{array}$} \\
\hline & Tebuconazole & $200 \mathrm{~g} / \mathrm{liter}$ & & & & \\
\hline & Trifloxystrobin & $100 \mathrm{~g} / \mathrm{liter}$ & 11 & & & \\
\hline \multirow[t]{2}{*}{ Amistar Xtra } & Cyproconazole & $80 \mathrm{~g} /$ liter & 3 & Syngenta & $0.5 \mathrm{ml}$ & $1 \mathrm{ml}$ \\
\hline & Azoxystrobin & $200 \mathrm{~g} / \mathrm{liter}$ & 11 & & & \\
\hline Aliette WG & Fosetyl aluminum & $800 \mathrm{~g} / \mathrm{kg}$ & 33 & Bayer & $1.25 \mathrm{~g}$ & $2.5 \mathrm{~g}$ \\
\hline Saprol & Triforine & $190 \mathrm{~g} /$ liter & 3 & Sipcam & $0.5 \mathrm{ml}$ & $1 \mathrm{ml}$ \\
\hline Bayfidan $250 \mathrm{EC}$ & Triadimenol & $250 \mathrm{~g} / \mathrm{liter}$ & 3 & Bayer & $0.25 \mathrm{ml}$ & $0.5 \mathrm{ml}$ \\
\hline Plantvax $750 \mathrm{WP}$ & Oxycarboxin & $750 \mathrm{~g} / \mathrm{kg}$ & 7 & Arysta & $0.65 \mathrm{~g}$ & $1.3 \mathrm{~g}$ \\
\hline Nordox 750 WG & Copper (cuprous oxide) & $750 \mathrm{~g} / \mathrm{kg}$ & M1 & Nordox & $0.5 \mathrm{~g}$ & $0.75 \mathrm{~g}$ \\
\hline Folicur $430 \mathrm{SC}$ & Tebuconazole & $430 \mathrm{~g} /$ liter & 3 & Bayer & $0.15 \mathrm{ml}$ & $0.3 \mathrm{ml}$ \\
\hline
\end{tabular}

${ }^{\mathrm{z}}$ The first five products were tested on both Lophomyrtus $\times$ ralphii and Metrosideros excelsa, whereas the remaining three products were tested only on L. $\times$ ralphii. All fungicides were applied in the equivalent of 500 liters/ha. FRAC $=$ Fungicide Resistance Action Committee.

Table 2. Timing of pre- and postinoculation fungicide applications in a trial to determine the efficacy of eight products for control of Austropuccinia psidii on two native New Zealand Myrtaceae species

\begin{tabular}{|c|c|c|}
\hline Treatment code & $\begin{array}{c}\text { Number of } \\
\text { applications }\end{array}$ & Time of applications \\
\hline Pre-7 & 1 & Sprayed with fungicides and left for 7 days before inoculation with A. psidii spores \\
\hline Pre-14 & 1 & Sprayed with fungicides and left for 14 days before inoculation with $A$. psidii spores \\
\hline Post-7/17 & 2 & $\begin{array}{l}\text { Sprayed with fungicide twice; first spray applied } 7 \text { days after inoculation with A. psidii spores } \\
\text { and second spray at } 17 \text { days }\end{array}$ \\
\hline Post-14/24 & 2 & $\begin{array}{l}\text { Sprayed with fungicide twice; first spray applied } 14 \text { days after inoculation with A. psidii spores } \\
\text { and second spray at } 24 \text { days }\end{array}$ \\
\hline Post-21 & 1 & Inoculated with A. psidii spores and left for 21 days before fungicide application \\
\hline
\end{tabular}


The application of the protective fungicides fosetyl aluminum (Aliette WG) and cuprous oxide (Nordox $750 \mathrm{WG)} \mathrm{to} \mathrm{L.} \times$ ralphii seedlings did not significantly reduce infection levels relative to the control at either the 18- or 35-day assessments. The same was observed for the active ingredients oxycarboxin (Plantvax $750 \mathrm{WP}$ ) and triforine (Saprol) (Table 4).

There was a significant main effect of timing of fungicide application (i.e., pretreatment or posttreatment with fungicide before or after inoculation) on mean infection scores for $M$. excelsa and $L . \times$ ralphii at both assessment dates (Supplementary Tables S1 and S2). The lowest percentage infection was generally achieved by the postinfection fungicide treatments applied as either Post-7/17 for $L . \times$ ralphii or Post-7/17 and Post-14/24 for M. excelsa on the 35-day infection score (Tables 5 and 6). Clearly, the plants benefited from the double spray postinoculation. Percentage infection of plants treated with a single prespray application, either Pre-7 or Pre-14, was significantly lower than the water controls at the 35-day assessment (abaxial leaf surface only for M. excelsa) for both species (Tables 5 and 6).

There was no significant effect of rate of fungicide (rate) application, recommended or double recommendation, on percentage infection scored on M. excelsa for either the 15- or 35-day LAA (Supplementary Table S1). There was a significant interaction between fungicide and timing for 15-day LAA (Supplementary Table S1). However, there was no significant interaction between fungicide and timing, fungicide and rate, time and rate, or all three factors for 35-day adaxial LAA and 35-day abaxial LAA assessed for $M$. excelsa (Supplementary Table S1). For $L . \times$ ralphii, there was a significant interaction between fungicide and timing for both the 18- and 35-day LAA (Supplementary Table S2).

The effect of timing of application for each of the fungicides tested on M. excelsa on the 35-day adaxial LAA is shown in Table 7 and on the 35-day abaxial LAA in Table 8. The two most effective fungicides, the cyproconazole/azoxystrobin and tebuconazole/trifloxystrobin mixes, achieved significantly reduced disease scores compared with

Table 3. Mean infection scores for Metrosideros excelsa inoculated with Austropuccinia psidii spores and treated with different fungicide formulations ${ }^{\mathrm{Z}}$

\begin{tabular}{llll}
\hline Treatment & 15-day LAA & $\begin{array}{c}\text { 35-day adaxial } \\
\text { LAA }\end{array}$ & $\begin{array}{c}\text { 35-day abaxial } \\
\text { LAA }\end{array}$ \\
\hline Water & $0.35(0.02) \mathrm{a}$ & $0.21(0.02) \mathrm{a}$ & $0.39(0.03) \mathrm{a}$ \\
Fosetyl Al & $0.32(0.01) \mathrm{ab}$ & $0.15(0.01) \mathrm{ab}$ & $0.28(0.02) \mathrm{b}$ \\
Triadimenol & $0.28(0.01) \mathrm{abc}$ & $0.09(0.01) \mathrm{c}$ & $0.22(0.02) \mathrm{bc}$ \\
Triforine & $0.30(0.01) \mathrm{abc}$ & $0.10(0.01) \mathrm{bc}$ & $0.21(0.02) \mathrm{bc}$ \\
Tebucon/triflox & $0.28(0.01) \mathrm{bc}$ & $0.05(0.01) \mathrm{c}$ & $0.17(0.02) \mathrm{c}$ \\
Cypro/azoxy & $0.26(0.01) \mathrm{c}$ & $0.05(0.01) \mathrm{c}$ & $0.14(0.02) \mathrm{c}$ \\
\hline
\end{tabular}

${ }^{\mathrm{z}}$ Standard errors are shown in parentheses. Values in a column followed by the same letter do not differ significantly (Tukey's test, $\alpha=0.05$ ). LAA = percentage leaf area affected; fosetyl $\mathrm{Al}=$ fosetyl aluminum; cypro/azoxy = cyproconazole/azoxystrobin; and tebucon/triflox $=$ tebuconazole/trifloxystrobin.

Table 4. Mean scores for Lophomyrtus $\times$ ralphii inoculated with Austropuccinia psidii spores and treated with different fungicide formulations ${ }^{\mathrm{Z}}$

\begin{tabular}{lllc}
\hline Treatment & \multicolumn{1}{c}{ 18-day LAA } & \multicolumn{1}{c}{ 18-day IAA } & 35-day infection score \\
\hline Water & $0.41(0.03) \mathrm{a}$ & $0.47(0.05) \mathrm{a}$ & $3.9(0.18) \mathrm{a}$ \\
Fosetyl Al & $0.39(0.02) \mathrm{a}$ & $0.34(0.03) \mathrm{abcd}$ & $3.8(0.13) \mathrm{a}$ \\
Cuprous oxide & $0.40(0.02) \mathrm{a}$ & $0.38(0.03) \mathrm{ab}$ & $3.8(0.13) \mathrm{a}$ \\
Oxycarboxin & $0.38(0.02) \mathrm{a}$ & $0.37(0.03) \mathrm{abc}$ & $3.7(0.13) \mathrm{a}$ \\
Triforine & $0.38(0.02) \mathrm{a}$ & $0.28(0.03) \mathrm{bcde}$ & $3.6(0.13) \mathrm{a}$ \\
Triadimenol & $0.34(0.02) \mathrm{ab}$ & $0.23(0.03) \mathrm{cde}$ & $2.7(0.13) \mathrm{b}$ \\
Tebuconazole & $0.29(0.02) \mathrm{abc}$ & $0.21(0.03) \mathrm{de}$ & $2.6(0.13) \mathrm{bc}$ \\
Cypro/azoxy & $0.26(0.02) \mathrm{bc}$ & $0.20(0.03) \mathrm{de}$ & $2.0(0.13) \mathrm{cd}$ \\
Tebucon/triflox & $0.22(0.02) \mathrm{c}$ & $0.15(0.03) \mathrm{e}$ & $2.0(0.13) \mathrm{d}$
\end{tabular}

${ }^{\mathrm{z}}$ Standard errors are shown in parentheses. Values in a column followed by the same letter do not differ significantly (Tukey's test, $\alpha=0.05$ ). LAA = percentage leaf area affected; IAA = internode area affected; fosetyl $\mathrm{Al}=$ fosetyl aluminum; cypro/azoxy = cyproconazole/azoxystrobin; and tebucon/triflox $=$ tebuconazole/trifloxystrobin. the control treatment for the Post-7/17, Post-14/24, and Post-21 treatments, with scores for all these treatments not differing significantly. Adaxial LAA was reduced more than abaxial LAA, which may be related to the inherently higher disease development characteristics and lack of sufficient fungicide coverage on abaxial leaf surfaces to manage the relatively higher fungal infections and growth. For the other fungicides tested, triforine and triadimenol both significantly reduced disease scores, although less than the two fungicide mixes. Fosetyl aluminum only produced a significant reduction in the adaxial LAA for the Post-14/24 treatment.

Results were similarly variable for $L . \times$ ralphii for the interaction between timing of fungicide application for the different fungicide treatments (Table 9). The 35-day IAA scores for the cyproconazole/azoxystrobin and the tebuconazole/trifloxystrobin mixes were significantly lower than those of the control treatment for all treatments except for the Post-21 treatment. There were no significant differences between the Pre-7, Post-7/17, and Post-14/24 treatments. Scores for the Pre-14 treatment were significantly lower than those of the control treatment but were higher than the other timing treatments. Tebuconazole produced significant reductions in 35-day infections scores for the Pre-14, Pre-7, and Post-7/17 treatments, and triadimenol for the Pre-7, Post-7/17, and Post-14/24 treatments. However, triforine only reduced scores significantly for the Pre-7 treatment, and oxycarboxin for the Pre-14 treatment, and none of the fosetyl aluminum and cuprous oxide treatments had any significant effect.

\section{Discussion}

The use of fungicides for disease control is an important component of any effective disease management program and will most likely be the case for the management of myrtle rust in New Zealand, particularly in the short term, in which people may want to protect large iconic trees or susceptible common Myrtaceae (native or exotic species) in public spaces or in commercial plant nurseries. Effective identification and use of fungicides to control diseases are highly dependent on understanding key factors that include the physiological,

Table 5. Mean disease assessment scores for Metrosideros excelsa inoculated with Austropuccinia psidii spores showing the effect of timing of fungicide application $^{\mathrm{z}}$

\begin{tabular}{lccc}
\hline Timing & 15-day LAA & 35-day adaxial LAA & 35-day abaxial LAA \\
\hline Water & $0.35(0.02) \mathrm{a}$ & $0.21(0.02) \mathrm{a}$ & $0.39(0.03) \mathrm{a}$ \\
Pre-7 & $0.22(0.01) \mathrm{b}$ & $0.15(0.01) \mathrm{a}$ & $0.22(0.02) \mathrm{b}$ \\
Pre-14 & $0.29(0.01) \mathrm{a}$ & $0.15(0.01) \mathrm{a}$ & $0.25(0.02) \mathrm{b}$ \\
Post-7/17 & $0.22(0.01) \mathrm{b}$ & $0.04(0.01) \mathrm{b}$ & $0.11(0.02) \mathrm{c}$ \\
Post-14/24 & $\ldots$ & $0.03(0.01) \mathrm{b}$ & $0.19(0.02) \mathrm{bc}$ \\
Post-21 & $\ldots$ & $0.07(0.01) \mathrm{b}$ & $0.25(0.02) \mathrm{b}$ \\
\hline
\end{tabular}

${ }^{\mathrm{z}}$ Note that only the 35-day assessments were carried out after all treatments were completed. Standard errors are shown in parentheses. Values in a column followed by the same letter do not differ significantly (Tukey's test, $\alpha=$ $0.05)$. LAA $=$ percentage leaf area affected.

Table 6. Mean disease assessment scores for Lophomyrtus $\times$ ralphii inoculated with Austropuccinia psidii spores showing the effect of timing of fungicide application ${ }^{\mathrm{z}}$

\begin{tabular}{lccc}
\hline Timing & 18-day LAA & 18-day IAA & 35-day infection score \\
\hline Water & $0.41(0.03) \mathrm{ab}$ & $0.47(0.05) \mathrm{a}$ & $3.9(0.18) \mathrm{a}$ \\
Pre-7 & $0.25(0.02) \mathrm{c}$ & $0.22(0.03) \mathrm{b}$ & $2.7(0.10) \mathrm{cd}$ \\
Pre-14 & $0.29(0.02) \mathrm{bc}$ & $0.18(0.03) \mathrm{bc}$ & $3.0(0.10) \mathrm{bc}$ \\
Post-7/17 & $0.25(0.02) \mathrm{c}$ & $0.11(0.03) \mathrm{c}$ & $2.4(0.10) \mathrm{d}$ \\
Post-14/24 & $0.40(0.02) \mathrm{a}$ & $0.39(0.03) \mathrm{a}$ & $3.2(0.10) \mathrm{b}$ \\
Post-21 & $\ldots$ & $\ldots$ & $3.8(0.10) \mathrm{a}$ \\
\hline
\end{tabular}

${ }^{\mathrm{z}}$ Note that only the 35-day assessments were carried out after all treatments were completed. Standard errors are shown in parentheses. Values in a column followed by the same letter do not differ significantly (Tukey's test, $\alpha=$ 0.05). LAA $=$ percentage leaf area affected, and IAA = internode area affected. 
biochemical, and molecular modes of action of the fungicides and the mechanisms required to avoid development of fungicide insensitivity in the long term. This study was a first step to improve our understanding of the potential to manage myrtle rust in New Zealand using fungicides.

Although all fungicides used in this study were shown to reduce infection levels relative to the control plants, the most effective fungicides were the triazole and strobilurin mixtures, notably the tebuconazole/trifloxystrobin and azoxystrobin/cyproconazole mixtures, compared with the single active ingredients used. This result is congruent with research reported elsewhere, in which a combination of tebuconazole/trifloxystrobin or azoxystrobin/cyproconazole was found to be effective against myrtle rust in E. grandis (Martins et al. 2014; Masson et al. 2011, 2013). This confirms that the systemic demethylation inhibitors, such as tebuconazole and cyproconazole, have certain properties that enhance their efficacy (Erincik et al. 2016; Zauza 2008). The effectiveness of the demethylation inhibitor fungicides can be explained by their uptake and systemic movement in plants, which facilitates early accumulation in the plant, and in sufficient amounts in plant tissue, to act against fungal growth (Erincik et al. 2016). Applied 7 days after infection, or in a double spray postinfection, the tebuconazole/trifloxystrobin mix tested in this study provided control of myrtle rust effectively at 35 days after inoculation for both host species tested. Similarly, Masson et al. (2011) showed that there was a significant control of the disease in E. grandis clones at 7 and 15 days after fungicide application. The combination of tebuconazole + trifloxystrobin at $1.5 \mathrm{~g} /$ liter was found to be the most effective against myrtle rust, reducing infection by $95 \%$ in $E$. grandis clones (Masson et al. 2011).

The Metrosideros plants generally grew a new pair of leaves every week, so although the 14-day preinoculation spray provided protection for the leaves scored, there was significant infection on younger leaves. Similarly, new growth was often severely infected on Lophomyrtus plants, although they grew leaves more slowly in comparison with the Metrosideros plants. As such, results from spraying 7 days before inoculation and 7 days after inoculation provided the most reliable indication of which treatments are likely to provide the best protectant and curative activity for myrtle rust. Although this information is good in theory, in practice it is not possible to translate this result into a recommendation for optimum timing to apply fungicides in relation to inoculation timing because myrtle rust spores are generally produced 10 to 12 days after inoculation, and in a natural environment spray operators will notice infection after 10 to 12 days of natural inoculation only and may miss the ideal time of fungicide application by at least 3 to 5 days postinoculation in natural ecosystems. It will be extremely useful if the optimum time for fungicide application can be extended out to 10 to 14 days before or after inoculation by using appropriate fungicide-adjuvant combinations that can prolong the life of the applied fungicides on plant surfaces or inside myrtle rust-infected plants. Hence, this study must be followed up by fungicideadjuvant bioefficacy studies using different classes of tank-mix adjuvants and adjuvant concentrations in combination with the most effective fungicides.

Table 7. Mean 35-day adaxial LAA for Metrosideros excelsa seedlings inoculated with Austropuccinia psidii spores showing the effect of timing of fungicide application for different fungicide treatments ${ }^{\mathrm{Z}}$

\begin{tabular}{llllll}
\hline Timing & Fosetyl Al & Triforine & Triadimenol & Cypro/azoxy & Tebucon/triflox \\
\hline Water & $0.21(0.02) \mathrm{ab}$ & $0.21(0.02) \mathrm{a}$ & $0.21(0.02) \mathrm{a}$ & $0.21(0.02) \mathrm{a}$ & $0.21(0.02) \mathrm{a}$ \\
Pre-7 & $0.25(0.03) \mathrm{a}$ & $0.13(0.03) \mathrm{abc}$ & $0.15(0.03) \mathrm{ab}$ & $0.08(0.03) \mathrm{bc}$ & $0.12(0.03) \mathrm{ab}$ \\
Pre-14 & $0.12(0.03) \mathrm{bc}$ & $0.17(0.03) \mathrm{ab}$ & $0.17(0.03) \mathrm{ab}$ & $0.13(0.03) \mathrm{ab}$ & $0.15(0.03) \mathrm{a}$ \\
Post-7/17 & $0.13(0.03) \mathrm{abc}$ & $0.02(0.03) \mathrm{c}$ & $0.03(0.03) \mathrm{c}$ & $0.00(0.03) \mathrm{c}$ & $0.00(0.03) \mathrm{b}$ \\
Post-14/24 & $0.07(0.03) \mathrm{c}$ & $0.05(0.03) \mathrm{bc}$ & $0.02(0.03) \mathrm{c}$ & $0.00(0.03) \mathrm{c}$ & $0.00(0.03) \mathrm{b}$ \\
Post-21 & $0.16(0.03) \mathrm{abc}$ & $0.11(0.03) \mathrm{abc}$ & $0.06(0.03) \mathrm{bc}$ & $0.02(0.03) \mathrm{bc}$ & $0.01(0.03) \mathrm{b}$ \\
\hline
\end{tabular}

${ }^{\mathrm{z}}$ Standard errors are shown in parentheses. Values in a column followed by the same letter do not differ significantly (Tukey's test, $\left.\alpha=0.05\right)$. LAA $=$ percentage leaf area affected; fosetyl $\mathrm{Al}$ = fosetyl aluminum; cypro/azoxy = cyproconazole/azoxystrobin; and tebucon/triflox = tebuconazole/trifloxystrobin.

Table 8. Mean 35-day abaxial LAA for Metrosideros excelsa seedlings inoculated with Austropuccinia psidii spores showing the effect of timing of fungicide application for different fungicide treatments ${ }^{\mathrm{z}}$

\begin{tabular}{llllll}
\hline Timing & Fosetyl Al & Triforine & Triadimenol & Cypro/azoxy & Tebucon/triflox \\
\hline Water & $0.39(0.03) \mathrm{a}$ & $0.39(0.03) \mathrm{a}$ & $0.39(0.03) \mathrm{a}$ & $0.39(0.03) \mathrm{a}$ & $0.39(0.03) \mathrm{a}$ \\
Pre-7 & $0.32(0.05) \mathrm{a}$ & $0.28(0.05) \mathrm{ab}$ & $0.23(0.05) \mathrm{abc}$ & $0.09(0.05) \mathrm{c}$ & $0.16(0.05) \mathrm{b}$ \\
Pre-14 & $0.26(0.05) \mathrm{a}$ & $0.21(0.05) \mathrm{b}$ & $0.26(0.05) \mathrm{abc}$ & $0.26(0.05) \mathrm{ab}$ & $0.25(0.05) \mathrm{ab}$ \\
Post-7/17 & $0.25(0.05) \mathrm{a}$ & $0.11(0.05) \mathrm{b}$ & $0.09(0.05) \mathrm{c}$ & $0.01(0.05) \mathrm{c}$ & $0.10(0.05) \mathrm{b}$ \\
Post-14/24 & $0.27(0.05) \mathrm{a}$ & $0.19(0.05) \mathrm{b}$ & $0.22(0.05) \mathrm{bc}$ & $0.13(0.05) \mathrm{bc}$ & $0.15(0.05) \mathrm{b}$ \\
Post-21 & $0.27(0.05) \mathrm{a}$ & $0.26(0.05) \mathrm{ab}$ & $0.29(0.05) \mathrm{ab}$ & $0.20(0.05) \mathrm{bc}$ & $0.22(0.05) \mathrm{b}$ \\
\hline
\end{tabular}

${ }^{\mathrm{z}}$ Standard errors are shown in parentheses. Values in a column followed by the same letter do not differ significantly (Tukey's test, $\left.\alpha=0.05\right)$. LAA $=$ percentage leaf area affected; fosetyl $\mathrm{Al}$ = fosetyl aluminum; cypro/azoxy = cyproconazole/azoxystrobin; and tebucon/triflox = tebuconazole/trifloxystrobin.

Table 9. Mean 35-day infection scores for Lophomyrtus $\times$ ralphii seedlings inoculated with Austropuccinia psidii spores showing the effect of timing of fungicide application for different fungicide treatments ${ }^{\mathrm{z}}$

\begin{tabular}{|c|c|c|c|c|c|c|c|c|}
\hline Timing & Fosetyl Al & Cuprous oxide & Oxycarboxin & Triforine & Triadimenol & Tebuconazole & Cypro/azoxy & Tebucon/triflox \\
\hline Water & $3.9(0.2) \mathrm{a}$ & $3.9(0.2) \mathrm{a}$ & $3.9(0.2) \mathrm{a}$ & $3.9(0.2) \mathrm{a}$ & $3.9(0.2) \mathrm{a}$ & $3.9(0.2) \mathrm{a}$ & $3.9(0.2) \mathrm{a}$ & $3.9(0.2) \mathrm{a}$ \\
\hline Pre-7 & $3.8(0.3) \mathrm{a}$ & $4(0.3) \mathrm{a}$ & $3.7(0.3) a b$ & $2.9(0.3) b$ & $2.7(0.3) b c$ & $1.9(0.3) \mathrm{c}$ & $1.6(0.3) \mathrm{cd}$ & $1.0(0.3) \mathrm{c}$ \\
\hline Pre-14 & $3.7(0.3) \mathrm{a}$ & $3.4(0.3) \mathrm{a}$ & $2.9(0.3) b$ & $3.8(0.3) a b$ & $3.4(0.3) a b$ & $2.5(0.3) b c$ & $2.4(0.3) b c$ & $2.0(0.3) b c$ \\
\hline Post-7/17 & $3.7(0.3) \mathrm{a}$ & $3.7(0.3) \mathrm{a}$ & $3.9(0.3) \mathrm{ab}$ & $3.1(0.3) \mathrm{ab}$ & $1.2(0.3) \mathrm{d}$ & $1.5(0.3) \mathrm{c}$ & $1.0(0.3) \mathrm{d}$ & $1.1(0.3) b c$ \\
\hline Post-14/24 & $4(0.3) \mathrm{a}$ & $4(0.3) \mathrm{a}$ & $4(0.3) \mathrm{ab}$ & $4(0.3) \mathrm{ab}$ & $2.3(0.3) \mathrm{cd}$ & $3.2(0.3) a b$ & $2.1(0.3) \mathrm{bcd}$ & $2.2(0.3) \mathrm{b}$ \\
\hline Post-21 & $4(0.3) \mathrm{a}$ & $4(0.3) \mathrm{a}$ & $4(0.3) \mathrm{ab}$ & $4(0.3) \mathrm{ab}$ & $4(0.3) \mathrm{a}$ & $3.7(0.3) \mathrm{a}$ & $3.0(0.3) \mathrm{ab}$ & $3.5(0.3) \mathrm{a}$ \\
\hline
\end{tabular}

${ }^{\mathrm{z}}$ Standard errors are shown in parentheses. Values in a column followed by the same letter do not differ significantly (Tukey's test, $\alpha=0.05$ ). Fosetyl Al $=$ fosetyl aluminum; cypro/azoxy = cyproconazole/azoxystrobin; and tebucon/triflox $=$ tebuconazole/trifloxystrobin. 
In general, controlling myrtle rust on Lophomyrtus stems and the abaxial leaf surface of Metrosideros plants was difficult. Part of the problem was ensuring spray coverage of Metrosideros stems, which have a low exposure area to a flat fan nozzle and the difficult-to-wet abaxial leaf surface (Gaskin 2017), which rarely gets effective fungicide application from a vertical fungicide spray. Appropriate application technologies and adjuvants may be able to aid in better spray coverage and retention on difficult-to-wet leaf surfaces of $M$. excelsa and should be the subject of further study. Results observed from the 7-day postinoculation sprays indicate that the route the fungus uses to colonize the plants may provide aid in fungicide penetration of the leaf material through chemical translocation through the fungal hyphae that are the infection units. This hypothesis requires validation through independent studies that examine the infection process of myrtle rust in conjunction with chemical applications.

In general, the rate of application plays a key role in the control of plant pathogens for many fungicides. Masson et al. (2011) showed that higher fungicide levels of azoxystrobin, tebuconazole, and trifloxystrobin led to a greater reduction of the disease in $E$. grandis clones. This was not found to be the case in this study, in which single and double fungicide application rates did not show any significant differences on levels of infection scored for all fungicides.

Besides the demethylation inhibitors, active ingredients in the strobilurin group were also used in this study. Strobilurins have been proved to suppress sporulation of fungi (Bartlett et al. 2002), and this is due to their biochemical mode of action, which disrupts the production of energy demanded by fungal development at various stages. The mode of action of the strobilurins contrasts with that of the demethylation inhibitor fungicides, which inhibit ergosterol biosynthesis and therefore do not prevent spore germination and early germ-tube development (Godwin et al. 1994). Although both fungicide groups (demethylation inhibitor and strobilurin) are systemic, they break the disease cycle at different points and thus differ in their role in the protection of plants from A. psidii infection (Mueller and Robertson 2008). Due to the different modes of action for the strobilurins and demethylation inhibitors (Mueller and Robertson 2008), a combination of the two tends to work effectively and efficiently. This was evident in this current study, because the application of these two different combinations (tebuconazole/trifloxystrobin or azoxystrobin/cyproconazole) performed relatively better than the application of either type alone.

In general, triadimenol and tebuconazole appear to be widely used stand-alone fungicides against myrtle rust (Martins et al. 2011; Ruiz et al. 1991). Their use as widely used stand-alone fungicides against myrtle rust is backed by research conducted elsewhere that indicated that tebuconazole (Masson et al. 2011) and triadimenol (Martins et al. 2011) applied as stand-alone fungicides were effective and reduced myrtle rust infection to a satisfactory level. The finding by Martins et al. (2011) was also supported by earlier trials (Alfenas 2004; Demuner and Alfenas 1991) that also showed that triadimenol is one of the most effective fungicides against myrtle rust. Zauza (2008) found that triadimenol was effective when applied in later phases of the disease cycle (i.e., as a curative treatment), which reduced inoculum levels and slowed the progress of myrtle rust infection. In addition, the results in South America from testing efficacy of fungicides against myrtle rust on guava (Martins et al. 2011; Ruiz et al. 1991) and Eucalyptus cloeziana (Alfenas 2004) affirm the superiority of triadimenol to other fungicides tested in their study. In the current study, triadimenol efficacy was found to be satisfactory and not significantly different from the fungicide mixtures on $M$. excelsa, and therefore it might be a more cost-effective option on $M$. excelsa compared with the fungicide mixtures. Similarly, in the case of $L . \times$ ralphii, triadimenol or tebuconazole generally did not perform significantly better than the fungicide mixtures, especially for the 18-day LAA and 35-day internode infection on L. $\times$ ralphii.

Although cuprous oxide has been reported to be effective as a protectant fungicide against myrtle rust in some studies (Ferreira 1989; Furtado and Marino 2003; Goes et al. 2004), this was not found to be the case for $L$. $\times$ ralphii in the present study. This could be due to differences in the characteristics of the host species as well as the timing and methods of applications, doses, and bioefficacy assessment used. The present study was on $L . \times$ ralphii, whereas research conducted in Brazil focused on Eucalyptus sp. (Furtado and Marino 2003) and $P$. guajava (Ferreira 1989; Goes et al. 2004). Goes et al. (2004) demonstrated that copper fungicides including cuprous oxide used for similar preventative trials in the field for control of myrtle rust on $P$. guajava were equally effective as the systemic tebuconazole. The application of fosetyl aluminum also did not effectively control myrtle rust in $L . \times$ ralphii. However, under in vitro conditions Subba Rao et al. (1992) reported on the ability of different concentrations of fosetyl aluminum to inhibit spore germination and germ-tube growth of peanut rust (Puccinia arachidis) on ground nut (Arachis hypogaea L.). According to Subba Rao et al. (1992), fosetyl aluminum prolonged the latent period of treated plants that were not Myrtaceae species.

To date, the most reliable method of controlling myrtle rust in New Zealand has been the use of fungicides, because nonchemical control strategies such as biological agents and myrtle rust-resistant cultivars have not yet been developed. A key research finding from this study is that timing of fungicide application is a significant and a critical aspect for optimum efficacy, as opposed to increasing rate of fungicide application. The findings can be used to provide practical recommendations for short-term control of myrtle rust in New Zealand. In addition, the study generated a necessary basis for further research to optimize fungicide formulation and application protocols for optimum protection of Myrtaceae species of economic and environmental significance against myrtle rust.

\section{Acknowledgments}

Thanks to Andrew Daly and Will Benson from NSW DPI for technical assistance during the trial.

\section{Literature Cited}

Alfenas, A. C. 2004. Fungicidas indicados para o controle de doencas em viveiros florestals. Pages 226-227 in: Clonagem e doenças do eucalipto. A. C. Alfenas, A. A. Valverde Zauza, and R. G. M. e. T. Francisco de A., eds. Editora UFV, Viçosa, Minas Gerais, Brazil.

Alfenas, A. C., Maffia, L. A., Macabeu, A. J., and Sartorio, R. C. 1993. Efficiency of triadimenol, oxycarboxin and diniconazole for rust (Puccinia psidii) control in coppice of Eucalyptus cloeziana under field conditions. Rev. Arvore 17:247-263.

Bartlett, D. W., Clough, J. M., Godwin, J. R., Hall, A. A., Hamer, M., and ParrDobrzanski, B. 2002. The strobilurin fungicides. Pest Manag. Sci. 58:649-662.

Beenken, L. 2017. Austropuccinia: A new genus name for the myrtle rust Puccinia psidii placed within the redefined family Sphaerophragmiaceae (Pucciniales) Phytotaxa 297:53-61.

Beresford, R. M., Turner, R., Tait, A., Paul, V., Macara, G., Zhidong, D. Y., Lima, L., and Martin, R. 2018. Predicting the climatic risk of myrtle rust during its first year in New Zealand. N. Z. Plant Prot. 71:332-347.

Berthon, K., Esperon-Rodriguez, M., Beaumont, L., Carnegie, A. J., and Leishmann, L. 2018. Assessment and prioritisation of plant species at risk from myrtle rust (Austropuccinia psidii) under current and future climates in Australia. Biol. Conserv. 218:154-162.

Carnegie, A. J., and Cooper, K. 2011. Emergency response to the incursion of an exotic myrtaceous rust in Australia. Australas. Plant Pathol. 40:346-359.

Carnegie, A. J., Kathuria, A., Pegg, G. S., Entwistle, P., Nagel, M., and Giblin, F. R. 2016. Impact of the invasive rust Puccinia psidii (myrtle rust) on native Myrtaceae in natural ecosystems in Australia. Biol. Invasions 18:127-144.

Carnegie, A. J., and Pegg, G. S. 2018. Lessons from the incursion of myrtle rust in Australia. Annu. Rev. Phytopathol. 56:457-478.

Chang, S., Soewarto, J., Adusei-Fosu, K., Rolando, C., Ganley, R., Padamsee, M., Waipara, N., Grant, A., Wegner, W., and Gee, M. 2018. Potential disease control tools most likely to be effective against Austropuccinia psidii. Ministry of Primary Industries, Wellington, New Zealand.

Clark, S., Eyles, D., Fieselmann, D., Van Eyndhoven, E., Ho, W., Gill, G., Burnip, G., Hurr, K., and Dalley, V. 2011. Risk Analysis of the Puccinia psidii/Guava Rust Fungal Complex (Including Uredo rangelii/Myrtle Rust) on Nursery Stock. Ministry of Agriculture and Forestry, Wellington, New Zealand.

Commonwealth Department of Primary Industries. 1985. Guava Rust: Puccinia psidii Winter. Plant Quarterly Leaflet, No. 45. Commonwealth Australia, Canberra, ACT.

Coutinho, T. A., Wingfield, M. J., Alfenas, A. C., and Crous, P. W. 1998. Eucalyptus rust: A disease with the potential for serious international implications. Plant Dis. 82:819-825.

Demuner, N. L., and Alfenas, A. C. 1991. Fungicidas sistêmicos para o controle da ferrugem, causada por Puccinia psidii em Eucalyptus cloeziana. Fitopatol. Bras. 16:173-176.

Erincik, Ö., Daldal, M., and Özkul, Y. 2016. Efficacy and timing of application of fungicides for plum rust control in Turkey. Crop Prot. 88:88-95.

Ferrari, J. T., Nogueira, C. E. M., and dos Santos, A. J. T. 1997. Control of rust (Puccinia psidii) in guava (Psidium guajava). Acta Hortic. 452:55-58. 
Ferreira, F. A. 1983. Ferrugem do eucalipto. Rev. Arvore 7:91-109.

Ferreira, F. A. 1989. Page 570 in: Patologia florestal: principais doenças florestais no Brasil. Sociedade de Investigações Florestais, Viçosa, Brazil.

Furtado, E. L., and Marino, C. L. 2003. Eucalyptus rust management in Brazil. Proceedings of the Second IUFRO Rusts of Forest Trees WP Conference, 2002, Yangling. China For. Res. 16:118-124.

Ganley, R. J., and Beresford, R. M. 2018. Confidential Report: Myrtle Rust. Ministry for Primary Industries (MPI), Crown Research Institutes (CRI)SCION, Manaaki Whenua, and Plant \& Food Research, New Zealand.

Gaskin, R. 2017. Confidential Report for the Ministry for Primary Industries. Plant Protection Chemistry New Zealand, Rotorua, New Zealand.

Glen, M., Alfenas, A. C., Zauxa, E. A. V., Wingfield, M. J., and Mohammed, C. 2007. Puccinia psidii: A threat to the Australian environment and economy-A review. Australas. Plant Pathol. 36:1-16.

Godwin, J. R., Young, J. E., and Hart, C. A. 1994. ICIA5504: Effects on development of cereal pathogens. Pages 259-264 in: Proceedings of the BCPC Conference on Pests and Diseases. BCPC, Farnham, U.K.

Goes, A., Martins, R. D., and Reis, R. F. 2004. Efeito de fungicidas cúpricos, aplicados isoladamente ou em combinação com mancozeb, na expressão de sintomas de fitotoxicidade e controle da ferrugem causada por Puccinia psidii em goiabeira [Effect of copper fungicides, sprayed alone or in combination with mancozeb, in expression of phytotoxicity symptoms and rust control caused by Puccinia psidii in guava]. Rev. Bras. Frutic. 26:237-240.

Marlatt, R. B., and Kimbrough, J. W. 1979. Puccinia psidii on Pimenta dioica in south Florida. Plant Dis. Rep. 63:510-512.

Martins, M. V. V., Silveira, S. F., and Maffia, L. A. 2014. Guava fruit loss caused by rust. Summa Phytopathol. 40:107-113.

Martins, M. V. V., Silveira, S. F., Maffia, L. A., Rocabado, J. M. A., and MussiDias, V. 2011. Chemical control of guava rust (Puccinia psidii) in the northern region of Rio de Janeiro State, Brazil. Australas. Plant Pathol. 40:48-54.

Masson, M. V., Moraes, W. B., and Furtado, E. L. 2013. Chemical control of eucalyptus rust: Brazilian experiences. In: Fungicides - Showcases of Integrated Plant Disease Management from Around the World. M. Nita, ed. InTech, Rijeka, Croatia.

Masson, M. V., Moraes, W. B., Matos, W. C., Alves, J. M., and Furtado, E. L. 2011. Eficiência e viabilidade econômica do controle químico da ferrugem do eucalipto em condições de campo [Economic viability and efficiency in chemical control of eucalyptus rust under field conditions]. Summa Phytopathol. 37:107-112.

McTaggart, A. R., Shuey, L. S., Granados, G. M., du Plessis, E., Fraser, S., Barnes, I., Naidoo, S., Wingfield, M. J., and Roux, J. 2018. Evidence that Austropuccinia psidii may complete its sexual life cycle on Myrtaceae. Plant Pathol. 67:729-734.

Moraes, W. B., Masson, M. V., Lima, A. C. V., Furtado, E. L., Silva, J. G., Chagas, H. A., and Boreli, R. 2011. Chemical application methods for eucalyptus rust control in the field. Proceedings of IUFRO Forest Protection Joint Meeting Colonia Del Sacramento, Uruguay.

Mueller, D. S., and Robertson, A. E. 2008. Preventative vs. curative fungicides. Integrated Crop Management News 798. Iowa State University, Ames, IA.

Pegg, G. S., Giblin, F. R., McTaggart, A. R., Guymer, G. P., Taylor, H., Ireland, K. B., Shivas, R. G., and Perry, S. 2014. Austropuccinia psidii in Queensland, Australia: Disease symptoms, distribution and impact. Plant Pathol. 63:1005-1021.

Ruiz, R. A. R., Alfenas, A. C., and Demuner, N. L. 1991. Efficiency of fungicides for the control of rust (Puccinia psidii) on guava (Psidium guajava). Summa Phytopathol. 17:147-153.

Simpson, J. A., Thomas, K., and Grgurinovic, C. A. 2006. Uredinales species pathogenic on species of Myrtaceae. Australas. Plant Pathol. 35:549-562.

Subba Rao, P. V., Geiger, J. P., Savary, S., and Ravise, A. 1992. Reactions of rust-infected groundnut genotypes following treatment with fosetyl-Al, $\alpha$-aminooxyacetate, and inoculation with Puccinia sorghi Schw. Oleagineux 47:573-578.

Tessmann, D., and Dianese, J. 2002. Hentriacontane: A leaf hydrocarbon from Syzygium jambos with stimulatory effects on the germination of urediniospores of Puccinia psidii. Fitopatol. Bras. 27:538-542.

Uchida, J. Y., and Loope, L. L. 2009. A recurrent epiphytotic of guava rust on rose apple, Syzygium jambos, in Hawaii. Plant Dis. 93:429.

Walker, J. 1996. Biogeography of fungi with special reference to Australia. Fungi Aust. 1A:263-320.

Winter, G. 1884. Repertorium. Rabenhorstii fungi europaei et extraeuropaei exsiccati cura Dr. Winter, Centuria XXXI et XXXII. Hedwigia 23:164-172.

Zauza, E. A. V. 2008. Eficiência de fungicidas sistêmicos no controle da ferrugem do eucalyptus. Rev. Arvore 32:829-835. 